\title{
Die funksie van Elihu (Job 32-37) in die boek Job
}

H Viviers

\section{ABSTRACT}

\section{The function of Elihu (Job 32-37) in the book of Job}

The Elihu speeches (Job 32-37) in the design of the book of Job are usually evaluated either totally redundant or literary fitting and functional. Why were they integrated in the book of Job, without adding anything new or profound? A literary-pragmatic analysis was done on these speeches to determine their function in Job. The text was analysed narratologically and poetically. This was complemented with insights from reception-criticism ("implied author", "implied reader") and pragmatics (politeness strategies) in order to also read "between the lines". The exigency for the integration of the Elihu speeches in the book of Job seems to be the ironic exposure of the doctrine of retribution.

\section{INLEIDING: PROBLEEMSTELLING EN WERKSWYSE}

\subsection{Probleemstelling: Pas Elihu in die boek Job in?}

Die Elihuredes (Job 32-37) in die boek Job word uiteenlopend beoordeel. Daar is eenstemmigheid dat hierdie redes sekondêr in die boek Job ingevoeg is, maar hier hou die konsensus op. Pas hierdie redes in die boek Job of is dit 'n geval van nommer onpas? Wat die Elihukorpus verder kompliseer is dat hier geen noemenswaardige nuwe teologiese bydrae tot die boek Job gelewer word nie. Die drie Jobsvriende verklaar Job se lyding as vergelding op sonde. Elihu skryf dit toe aan opvoedkundige tugtiging, maar volledig in lyn met die tradisionele vergeldingsleer ${ }^{1}$. Hy kry egter die langste aaneenlopende spreekbeurt. Die vraag is, waarom is dit so? As die aksent op sy bydrae dan nie in inhoud lê nie, waarin lê dit dan?

Die pas (al dan nie) van die Elihuredes in die boek Job loop in twee teenoorstaande rigtings uiteen. Daar is diegene wat dit as 'n lomp, latere redaksionele invoeging beskou. Die funksie wat hierdie standpunt aan Elihu toeken, is dat dit die behoeftes van 'n baie konserwatiewe groep (waarskynlik in wysheidskringe) moes bevredig. Dit moes die felle protes van die boek Job teen die vergeldingsdogma versag, byna soos die slot van 
die boek Prediker. Hierdie ortodokse stempel sou dan daartoe meewerk dat Job uiteindelik ook sy weg tot in die kanon gevind het ${ }^{2}$. Lynreg hierteenoor is daar die standpunt wat die latere invoeging van Elihu erken, maar van oordeel is dat dit netjies in die geheel van die boek inpas. Die integrering self kan as baie kunstig beskryf word, sodanig so dat die stemme van die karakter Elihu, die skeppende verteller en die kritiese digter byna as die werk van 'n uiters oorspronlike "outeur" beskryf kon word. Elihu pas forensies in die boek in: Job het in hoofstuk 31 vir God gevra vir litigasie en Elihu neem dan in die plek van God die rol as arbiter in hierdie regsgeding op. Die Elihuredes het ook 'n literêr-dramatiese rol: dit vertraag die intrige voor God se verskyning in hoofstuk 38 en veroorsaak so 'n antiklimaks in die storielyn ${ }^{3}$.

Albei hierdie standpunte verdien 'n her-evaluering en daar sal veral gepoog word om die funksionele rede agter die invoeging van die Elihuredes te beantwoord. Sê 'n deel wat eintlik niks sê nie, dan werklik niks nie?

\subsection{Werkswyse: Literêr-pragmaties}

'n Literêr-pragmatiese ondersoek hou groot belofte in vir die ondersoek na 'n teks wat klaarblyklik iets anders as net blote inhoud wil kommunikeer.

Met literêr (struktureel) word bedoel dat die Elihuredes volledig as literatuur ondersoek word. Die taal van die teks word fonologies, sintakties en semanties onder die loep geneem. Narratiewe konvensies in die Elihuredes self (bv karakterisering) en in die geheel ${ }^{4}$ van die boek Job (bv intrige) kry aandag. Die Elihuredes bestaan uit poësie en daarom word daar ook op enkele poëtiese konvensies gefokus. 'n Literêre benadering verskaf egter nie die volledige antwoord na die "hoekom" van 'n bepaalde teks nie. Om dié rede moet dit aangevul word met insigte wat fokus op die pragmatiese gebruik van taal (vgl lesers-georiënteerde benaderings) ${ }^{5}$. Hier gaan dit oor die kommunikatiewe kompetensie van 'n teks. Waar eersgenoemde veral fokus op die lokusie (stellende betekenis) van taal, wil pragmatiek fokus op die illokusie (effek op die gehoor) van taalgebruik, en ook perlokusie (effek wat werklik bereik is). 'n Teks is nie slegs 'n objek nie, maar is iets lewendig6. Taal is 'n handeling ("speech act"), is sosiaal ingebed en word gebruik om sosiale interaksie te bewerk. 'n Spreker/skrywer is gedurig besig om "transaksies" aan te gaan met die gehoor/leser en die retoriese (kommunikatiewe) situasie speel hierin 'n wesenlike rol7. Nie alles wat 'n skrywer wil sê, lê in die teks voorhande nie. Daar is baie "onuitgesproke" bedoelinge ${ }^{8}$ wat "tussen die lyne" en 
"agter die teks" (nie in historiese nie, maar retoriese sin bedoel) lề Hoewel hierdie studie nie poog om 'n retoriese studie in die ware sin van die woord te wees nie ${ }^{10}$, is dit ' $n$ tree of wat in daardie rigting: 'n studie in die kuns van oorreding deur die interaksie tussen 'n skrywer (orator), teks (gesprek) en leser (gehoor) na te gaan ${ }^{11}$.

Die instrumente wat aangewend word vir veral die ondersoek na dit wat "tussen die lyne" van die Elihuteks staan, is die volgende: die literêre konstrukte van implisiete outeur en implisiete leser wat keersye vorm van mekaar. Die vlees-en-bloed-outeur kan deur 'n teks op geen ander manier uitreik na die vlees-en-bloed-lesers as deur die geïmpliseerde leser of beeld of voorstelling wat hy van hulle het nie. Die vlees-en-bloedlesers kan op geen ander manier deur die teks die werklike outeur ontmoet as deur die implisiete outeur of beeld wat hulle van hom het nie. Beide hierdie fiktiewe konstrukte is linguïsties, literêr, kultureel en deur ander kodes in die teks geënkodeer. Deur die implisiete outeur verskaf die outeur sekere lesersinstruksies of wenke (artistieke pool van die teks) wat deur die implisiete lesers (estetiese pool van die teks) geaktualiseer word. Die implisiete outeur kan veral geëien word deur die outeur se geënkodeerde waardes, oortuiginge en belangstellings in die teks. Die somtotaal van wat in die teks geënkodeer is werk mee tot die profielvorming van die implisiete leser. Ook die vul van "gapings" in die teks deur retrospeksie en antisipasie (intra- en intertekstuele kompetensie word dus veronderstel), soos wat die leesproses temporeel (al lesende realiserende) voltrek word, werk hiertoe mee. So kom die beeld van die implisiete leser mettertyd al duideliker na vore. Karakterisering van Elihu veral in die Elihuteks help om die beeld van die implisiete leser te vorm ${ }^{12}$.

Omdat Elihu hééltyd in gesprek met Job en die vriende is, is ook 'n gespreksanalise van die Elihuteks gedoen, naamlik die gebruik van hoflikheidstrategieë. Dit dra verder by tot die karakterisering van Elihu. Hoflikheidstrategieë wissel van minder hoflik na uiters hoflik: daar is die "op-die-man-af"-strategie ("Bald-on-record"), positiewe hoflikheid (meer intieme, familiêre taalgebruik), negatiewe hoflikheid (indirekte, formele taalgebruik) en "off-record"-strategie (dubbelsinnig, vaag). Telkens is die sprekers se "aansien" ("face") ter sprake en sosiale faktore soos sosiale afstand, statusverskille ten opsigte van magsposisie en die impak van die gesprek ("face-threatening act"), asook geslags- en kultuurverskille speel alles 'n rol in die keuse van 'n gesprekstrategie ${ }^{13}$. Toegepas op die "gesprek" tussen die implisiete outeur en implisiete leser, werp dit interessante lig op die kunsgehalte van die boek Job.

Retoriese tegnieke soos pathos (emosionele beroep) en ethos (persoonskildering) dra ook tot die karakterisering van Elihu en die 
profieltekening van die implisiete leser by ${ }^{14}$. Retoriese situasie (verskil van historiese) kry ook kortliks aandag.

Daar word sterk gesteun en voortgebou op veral die werke van Norman Habel ${ }^{15}$ oor Job. Sy intensiewe literêre lees van die teks plaas hom dadelik ook "tussen die lyne" en "agter die teks".

\subsection{Vertellersproloog: Opsomming van die Elihu regsdiskoers}

Hoofstuk 32:1-6a is in prosa geskryf en vorm deel van die prosaraam van Job $^{16}$. Die proloog verskaf nie alleen 'n kort situasiesketsing nie, maar gee ook reeds belangrike inligting oor die implisiete outeur en verteller.

Hoewel Job na-eksilies ( $\pm 4 \mathrm{e}$ eeu vC) gedateer word, speel die verhaal in die heroïese patriargale tydvak af (vgl argaïese benaminge vir God). Elihu is 'n nuwe karakter op die toneel. Die verwysing na sy voorsate is eerder karaktertekenend as histories bedoel. Hy kom uit 'n respektabele Israelitiese familie. Hy is dus nie 'n indringer nie. Die verteller stel hom met die intrapslag (en antisipeer wat verder volg) as 'n jong impulsiewe heethoof bekend. Vier maal word daar in vers 2-5 gesê dat sy "toorn ontvlam het". Dit word verder onderstreep deur die inclusio $^{17}$. Nadat die drie vriende misluk het, wil Elihu die reg van Job in sy eie oë weerlê. "Téén Job" (v 2) en "téén sy drie vriende" (v 3), staan in emfatiese posisies en bevestig die afstand 18 tussen Elihu en die vriende. Terselfdertyd wil hy God se eer beskerm - sy naam wat beteken "Hy is my God" 19 sinspeel subtiel aan wie se kant hy in die verdere hoofstukke is. Elihu wil dit doen deur Job te "antwoord". ענה tesame met Job se "woorde" (31:40) en Elihu s'n (v 4) moet forensies ${ }^{20}$ verstaan word. Elihu "gee" nou vir Job die "hofsaak" waarvoor hy in hoofstuk 31 gevra het. Tנה (vers 6, 34:1, 35:1 ens) word daar subtiel hierop gesinspeel. Die rede vir hierdie regsgeding (retoriese situasie) word later weer aangeraak.

Die verteller en implisiete outeur sou hier kon saamval ${ }^{21}$ om die leser in die leesproses te lei, maar word tog onderskei. In die proloog leer ons die verteller ken as 'n derdepersoons-, betroubare, nie-opdringerige verteller. Laasgenoemde word veral bevestig deur die kort en kragtige proloog wat baie neutraal aangebied word. Ook die stil, interpreterende "stem" van die implisiete outeur agter die verteller respekteer eweneens die kritiese eie oordeel van die leser. Hoewel die proloog as sodanig nie veel van die outeur se waardes, oordele en oortuigings ${ }^{22}$ reflekteer nie (die 
profiel of beeld van die implisiete outeur kry immers vorm of groei uit die hele boek Job), kry ons tog hier 'n onderbeklemtoonde "afwysing" van die heethoofdigheid van Elihu en per implikasie van sy wysgerige standpunt. Hier reeds ontvang die implisiete leser 'n "wenk" hoe om Elihu te weeg. Die leser se wenkbrou behoort te lig oor Elihu se ethos. Hierdie oordeel kom tot volle openbaring in die gedurige, subtiele ontmaskering van Elihu hiervandaan verder. Die epiloog in Job dryf die finale spyker in die doodskis van die Elihustandpunt (die vergeldingsdogma) in.

\subsection{Elihu se apologie}

Hoofstuk 32:6 vorm 'n skarnier tussen die prosaproloog en die poësieredes van Elihu wat verder volg. In plaas van om indirek te rapporteer oor Elihu se standpunt laat die verteller hom (soos die ander vriende en ook God later) in die direkte rede in poësie praat om die gesprek te verlewendig23. Elihu se karakter word "gewys" 24 . Enersyds is dit 'n waagstuk, want Elihu is besonder welsprekend. Andersyds word Elihu se geleentheid vernuftig in 'n verleentheid omskep. Die direkte aanhaling van gesprekke as getuienis was gebruiklik by hofprosedures (Jer $26: 9,18)^{25}$ en Elihu doen dit ook deurgaans. Wanneer hyself egter volledig aangehaal word, stel dit die implisiete leser in staat om self 'n oordeel (as "regter") oor Elihu te vel.

Elihu se apologie (32:6b-22) bestaan uit drie onderafdelings ${ }^{26}$, naamlik vers 6b-10: Elihu is jonk, maar van nature kán en wíl hy sy insigte deurgee; vers 11-16: Hy wag tevergeefs op die "regte" antwoord aan Job deur die vriende; vers 17-22: Hy is tot barstens toe "vol" van wysheid oor Job se saak en in sy oë heeltemal onpartydig. Besondere moeite met die karakterisering van Elihu word hier reeds vroeg in die gesprek gedoen: Elihu "groei" van nederige jong wyse (v 6-7) tot 'n opgeblase, welsprekende dwaas.

Vers $6 b$ is chiasties gerangskik om die ouderdomsverskil tussen Elihu en die vriende te benadruk. Klankspel lê 'n subtiele band tussen צִצִיר

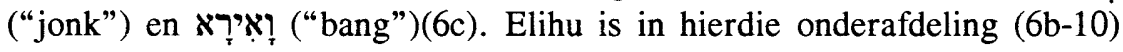
besonder hoflik. Hy plaas hom in die skoene van die vriende deur hulle aan te haal ${ }^{27}$. Hy gebruik onpersoonlike ${ }^{28}$, hoflikheidsterme ${ }^{29}$, die epitheta "dae", "baie jare", "bejaardes" en "oues" om die afstand tussen hom en die vriende te erken. Hy sluit aan by roemryke voorgangers soos Gideon (Rig 6:15), Saul (1 Sam 9:21) en Jeremia (Jer 1:6) om sy jeugdige ontoereikendheid te erken ${ }^{30}$. Sy nederigheid is egter van korte duur. Hy sien homself as 'n natuurlik-begiftigde met wysheid (v 8). Sy gesprekstrategie verander van negatiewe hoflikheid (erkenning van sosiale afstand) 
na 'n direkte "op-die-man-af" strategie in vers 10 en gee dadelik aan homself meer mag. Dit word bevestig deur die imperatief in vers 10 wat as "aandagtrekker" 31 funksioneer: "Luister...". Die uitgange in vers 10 onderstreep ook klankgewys Elihu se al groter wordende egosentrisme. Waar Elihu in vers $6 \mathrm{c}$ gehuiwer het om sy kennis mee te deel kan hy in vers 10 skaars wag om dit te doen. So word hierdie eerste deel van die gesprek ook omraam deur inclusio.

Elihu se "op-die-man-af" gesprekstrategie word in vers 11-16 voortgesit. Hier word die vriende direk as "julle" aangespeek en nie meer respekvol as "hulle" nie. Hulle word ook dadelik aangeval omdat hulle geen "antwoord" (vgl weer die stam ענה wat so volop voorkom in hierdie hoofstuk) kan kry om Job te weerlê nie. Hier word dus op hulle tekort aan wysheid in die vorige deel voortgebou. Twee chiasmes beklemtoon Elihu se tevergeefse wag op 'n antwoord: verse 11-12 vorm 'n chiasme en so

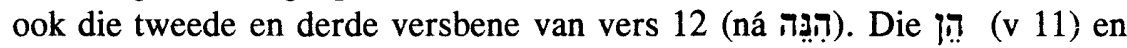
הִּנ: ( $\mathrm{v}$ 12) partikels dra hiertoe by. Die chiasme tussen vers 15 en 16 wat die gedeelte afsluit om saam met הוֹחָלְתִ inclusio te vorm, het dieselfde funksie. Die implikasie van vers 12 "geen arbiter" (מוֹכִיח) en "geen antwoord" nie, is dat Elihu homself in hierdie rol sal aanstel ${ }^{32}$. Waar die vriende in vers 13-14 huiwerig is om verder 'n oordeel te vel, want slegs God beskik oor hierdie vermoë (vgl 28:23), sien Elihu hier kans om God se rol te speel soos hy later ook gereeld doen. Hy is gereed vir die hofsaak waarin Job hom moet "opstel” (צר) (צר). In vers 15-16 neem Elihu sommer ook die rol van die verteller ${ }^{33}$ oor: "Hulle staan verslae...". Die retoriese vraag in vers 16 dui vir die implisiete leser die sogenaamde "gevegsgrond" 34 aan waarom dit eintlik gaan: Is Job of God reg? Kan die vergeldingsdogma gehandhaaf word?

In die laaste onderdeel van hierdie hoofstuk, naamlik verse 17-22, val die soeklig skerp op Elihu. Soos wat hy die eerste onderdeel afgesluit het (v 10), so begin hy ook die laaste onderdeel. Die chiasme in vers 17 benadruk Elihu se byna kompulsiewe drang om te "antwoord". Die

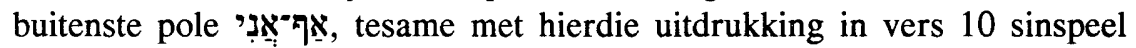

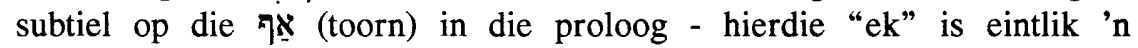
heethoof 35 . Hy praat dan ook te verstane "op-die-man-af" en "ek"gesentreerd. Die vergelykings in vers 18 en 19 vervul 'n belangrike rol in Elihu se (ware) karaktertekening deur die "stem" van die implisiete outeur. Elihu sê hy is "vol van woorde en van gees" (vgl ook v 8; let ook op die klankspel tussen "gees" [v 18] en "lug" kry [v 20]), tot barstens toe vol soos 'n wynsak wat enige oomblik die gees gaan gee. Tot dusver was Elihu besig om 'n etiese appèl (ethos) ${ }^{36}$ tot sy toehoorders te rig om homself te 
verdedig as geskik om te "antwoord". Hier doen hy dit pertinent en oordrewe. Elihu blaas homself op, maar word deur vlymskerp ironie ontmasker. Voorafkennis by die leser van 15:2-3, waar Elifas sarkasties spot met iemand wat voorgee hy is wys, maar slegs vol wind is, word veronderstel. Nou kom Elihu (ernstig) en hy prys homself hiermee aan. Tereg noem Habel ${ }^{37}$ Elihu 'n windsak. Al klink die jong wysgeer soos 'n profeet ${ }^{38}$, (Jer 20:9) is hy dit allermins. Ook die beeld van wyn kry 'n negatiewe konnotasie vanuit Spreuke 20:1 - 'n dronkaard kan nie wys wees nie. En nog eens ironie in vers 21-22: Ten spyte van Elihu se versékering

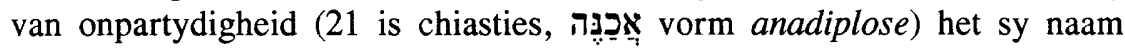
hom reeds weggegee in die proloog, en kan geantisipeer word wat later gaan volg. Elihu se ethos lê aan skerwe.

Hiermee is deur die apologie die tafel reeds gedek vir die geïmpliseerde leser om te weet wat verder verwag kan word. Elihu begin nederig, maar eindig as 'n opgeblase, selfaangestelde wysgeer-regter. Hy is deursigtig en hy het uit en uit "the makings of a fool" 39 (vgl Spr 12:15; 14:17).

\subsection{Elihu en Job (die aanloop tot die hofgeding): God antwoord indirek}

Hoofstuk 33, waarin Elihu hom nou tot Job wend, bestaan uit die volgende onderafdelings: vers 1-7: 'n Apologie in die kleine teenoor Job en oproep tot 'n hofgeding; vers 8-14: Job se onskuld ernstig bevraagteken; vers 1528: God "antwoord" wel deur drome (15-18), fisiese lyding (19-22) en na bemiddeling en belydenis - in die kultus (23-28); vers 29-33: God red en weer 'n oproep aan Job om aan Elihu gehoor te gee.

Elihu is in vers 1-7 steeds op sy "ontblotende" selfverheerlikingstog soos in die afsluitingsdeel van die vorige hoofstuk. Sy aanslag bewys dit. Hy roep Job "op-die-man-af" op om na hom te luister (weer "aandag-

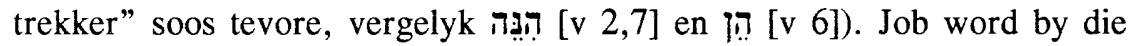
naam aangespreek, iets wat die vriende nie gedoen het nie ${ }^{40}$. Hy verdedig sy persoon (ethos) deur die beklemtoning (deur chiasme) van sy opregtheid (v 3) ${ }^{41}$. In vers 4 sinspeel hy soos voorheen op sy goddelike begaafdheid as wysgeer en dan sarkasties, "op-die-man-af" (deur imperatiewe), "Antwoord my as jy kan” (v 5). Oënskynlik plaas Elihu homself in Job se skoene deur hulle as gelykes te beskou om so Job se vrees te besweer (v 67). Veronderstelde kennis van 13:17-28 bring Elihu se ware kleure egter na vore. In hierdie hoofstuk daag Job vir God tot 'n openbare verhoor uit sodat God hom moet ophou teister. Elihu neem God se rol oor. Job hoef sy 
teistering nie te veel te vrees nie ( $\mathrm{v} 7$ ). Elihu se grootheidswaan het klaarblyklik geen perke nie.

In vers 8-14 kry Elihu se ethos 'n verdere knou. Die doel van die aanhaling van Job se woorde is om dit as getuienis te toets. Die implisiete leser kry terselfdertyd die wenk om Elihu te toets. Job het nooit gesê hy is volledig onskuldig ( $\mathrm{v}$ 9) soos Elihu hom met nadruk (klankspel tussen [ $v$ 8] en 7? [ $v$ 9] en soortgelyke begin van 2 versbene van $v$ 9) aanhaal nie. Hy het ook gesondig $(8: 21 ; 13: 26)$, maar nie om soveel smart te verdien nie $^{42}$. Is Elihu dus so opreg en suiwer soos wat hy in vers 3 sê? Die "opdie-man-af" antwoord (soos voorheen) in vers 12 dat God gróót en verhewe is, is irrelevant. Job het dit reeds erken $(9: 1-13 ; 12: 13-25)^{43}$. Wanneer Elihu in vers 13 impliseer dat God nie hoef te "antwoord" omdat Hy nie skuldig is nie, suggereer (en antisipeer) hy Job se skuld.

Hoewel vers 14 by die voorafgaande onderdeel aansluit, vorm dit ook 'n skarnier na onder (v 15-28) toe: God praat indirek op verskeie (vgl die getallespreuk) ${ }^{44}$ maniere. Anders as Job, wat direk aangehaal word, doen Elihu dit nie met God nie. God hoef nie "getoets" te word nie, al dink Job miskien so. Die doel van die droomopenbaring (v 15-18) is om die mens (Job word geïmpliseer) van kwaad te weerhou (v 17: chiasme) en

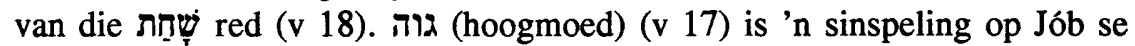
opstand teen God.

Ook die fisiese lyding sinspeel op Job. Job het gevra vir 'n openbare verhoor deur God en nou kry hy 'n "verhoor", maar wel in sy liggaam (v 19-22)45. God "straf" (vgl die passief waarmee v 19 begin) hom reeds vir sy sonde. Sy eie toestand is 'n bewys hiervan. Elihu kan maar net nie aanvaar dat Job ten spyte van sy herhaalde betoë onskuldig is nie. Soos by die vorige onderdeel word ook hierdie onderdeel met die dreiging van שָָׁ (v 22: chiasme) afgesluit en in vers 23-28 argumenteer Elihu in dieselfde trant voort. Hoewel nie eksplisiet so gestel nie, sien Elihu homself as die verlossende engel (waarna Job ook vroeër gevra het) ${ }^{46}$ om Job weer op die regte pad te kry, nog heeltyd sy selfopgelegde taak. Hy sal Job red van שָָָׁ (v 24), sy liggaam sal genees (v 25) en hy sal weer na God terugkeer. Hy erken openlik, bely asof in die kultus en getuig van God se genade ( $v v 27,28)^{47}$. Dít is die kern van die probleem: Job is skuldig, daarom ly hy. Hoewel Elihu nooit Job in hierdie drie onderafdelings direk noem nie, impliseer hy hom heeltyd as die skuldige en probeer hy op 'n slinkse manier om 'n skulderkenning uit hom te pers ${ }^{48}$. Weer eens ondermyn hy sy ethos van sogenaamde opregtheid vroeër in vers 3 .

Vers 29-30 van die laaste onderdeel (v 29-33) sluit ook die voorafgaande deel af: vers 28 en 30 se eerste versbene is parallel en die 
tweede is chiasties gerangskik: God red en $\mathrm{Hy}$ gee lewe. "Al hierdie dinge" (v 29) verwys terug na sy indirekte bekendmaking, ontdekking van sonde en skuldbelydenis (vir Job se ore bedoel) en herstel voor God. As Elihu hierdie saak so goed onder die knie het dan kan hy sy gesprek met groter oortuiging afsluit (vv 31-33) en saambind (deur inclusio) soos hy begin het. Sy styl is weer "op-die-man-af" en uitdagend. Al sou Job wel 'n paar woorde kon kwytraak, omvou Elihu se woorde (vv 31,33) syne. Hy sal die laaste woord hê as die wyse leermeester ( $v$ 33). Op grond van Spreuke 17:27-28 weet die leser egter dat 'n ware wyse eintlik sy woorde inhou en beheersd is ${ }^{49}$.

\section{$2.4 \quad$ Die hofgeding}

Die verteller stel Elihu hier in hoofstuk 34 weer aan die woord deur hom te laat "antwoord". Die hoofstuk is uit die volgende dele saamgestel: in vers 2-9 identifiseer Elihu sterk met die "jurie" (die "wyses"); vers 10-15: die verhewe God is ver van onregverdigheid; vers 16-33: die verdediging van God om Job tot 'n skulderkenning te beweeg. Die onderafdelings is vers 16-20: God wat volmaak heers, kan nie skuldig wees nie; vers 21-25: God sien alles en kan oordeel sonder 'n regsaak; vers 26-30: God vergeld volgens dade; vers 31-33: "Bely jou skuld Job!"; in die afsluitingsdeel vers 34-37, vind Elihu en die "jurie" Job skuldig.

Elihu volg in vers 1-9 'n ander gesprekstrategie as tot dusver, naamlik dié van positiewe hoflikheid ${ }^{50}$. Die "afstand" tussen Elihu en die "wyse manne" van die gemeenskap is klein. Hy spreek hulle wel direk aan (vgl die chiasme; vgl ook 33:1). Hulle is egter vennote soos uit vers 4 se "ons" blyk. Die chiasme in vers 4 onderstreep hierdie goeie samewerking. Hulle epitheta is vleiend: "wyses", "verstandiges" en hierdeur "salf" hy hulle gesigte ${ }^{51}$. Presies só sien Elihu homself (vgl 33:33) ook en daarom kan hy so sterk met hulle identifiseer. Die implisiete leser kan by voorbaat Elihu en hierdie jurie se partydigheid (ethos) bevraagteken. In vers 5 haal Elihu weer vir Job aan soos voorheen (vgl 33:9). Sy "onskuld", wat mooi beklemtoon word deur die anadiplose van "ִ̣ en chiasme (v 6), is die saak ter tafel. Vers $7-8$, waarin Job by voorbaat skuldig bevind word, is eintlik voorspelbaar. Die retoriese vraag wil nie "inligting" hê nie, maar "instemming" 52 dat Job skuldig is. In vers 9 volg 'n aanhaling ter getuienis van Job se skuld. Ironies genoeg, kan die hofsaak teen Job nou begin.

Met Job by voorbaat skuldig, begin Elihu met 'n verdediging van God se onskuld (v 10-15). Met klankspel (a-i-e en l) in $10 \mathrm{~b}$ en sterk nadruk (openingswoorde) in vers 12 distansieer Elihu God van verkeerde optrede. 
Elihu reageer op Job se aanval in 12:13-25 oor God se wanbestuur van die wêreld. God kan nie fouteer nie, want $\mathrm{Hy}$ werk volgens die vergeldingsdogma ( $v$ 11). Weer weier Elihu om te aanvaar dat God dalk anders kán werk, sonder die vergeldingsdogma wat Job wil sê. Verkeerde "weë" en "dade" wys onmiskenbaar terug na Job se dade in vers 8. Die retoriese vrae in vers 13 impliseer dat iemand so verhewe soos God slegs rég kan handel. Vers 14 en 15 beklemtoon (beide is chiasties) God se soewereiniteit.

In vers 16-20 (en tot v 33) wend Elihu hom tot Job. Anders as sy kollegas word Job "op-die-man-af" gekonfronteer (vgl die imperatiewe in $\mathbf{v}$ 16). Elihu gaan in dieselfde trant as by die vorige onderdeel voort. Hier val die klem egter op God wat regeer. Hy kan konings en vorste slegsês3 (vgl die chiasme in v 18), Hy trek nie voor nie ( $\mathrm{v} 19$ ) en Hy is almagtig en soewerein (soos in v 15) om gesiene mense ${ }^{54}$ en sterkes te laat omkom. Die geïmpliseerde antwoord op die retoriese vraag in vers 17 is duidelik: uit God se heerskappy blyk sy regverdigheid.

In vers 21-25 word God se regverdige oordeel die beklemtoon. Hy sien alles (vv 21-22). Hy het nie nodig om 'n hofgeding te hou nie (vv 23-24) en straf die skuldiges volgens hulle dade. Hoewel Elihu in vers 21 God se alsiendheid chiasties beklemtoon, het Job dit al vantevore gesê (7:8). Die verskil is dat Job voel dat God hom sonder rede bespied, terwyl Elihu impliseer dat God reg optree, want daar lê maar altyd sonde iewers weggesteek (ook by Job) en die straf daarop is dan regverdig. Die implisiete leser wat tot dusver baie behendig gelei is om krities teenoor Elihu te staan, moet toegee dat hy absoluut konsekwent in sy vergeldingsdogmadenke is.

In vers 26-30 kom wesenlik dieselfde gedagtegang na vore: geregverdigde straf op verkeerde dade. Die "openbare plek" van straf (v 26) sinspeel op Job op die ashoop - 'n bewys van sy skuld. Om God te verlaat en die minderes te vertrap (sowel $v 27$ as $v 28$ is chiasties) is sulke dade, al het Job homself male sonder tal verdedig oor sy naasteliefde. God kan tog nie 'n fout mak en verniet straf nie. Die retoriese vrae in vers 29 wys terug na vers 13 toe: die verhewe God is regverdig. Daarom sal Hy sorg dat geen goddelose regeer nie ( $\mathrm{v} 30$ ). Hierdie God tree net rég op, en rég beteken vir Elihu 'n vaste oorsaak en gevolg.

Die gesprek met Job is besig om saam te sluit in vers 31-33. Elihu beweeg van praat "oor" God weer na "jy" Job, en soos voorheen aggressief "op-die-man-af": "Bely skuld..." (vgl אמר impt in 31 en impt דבר in 33 waarmee die deel afsluit). In hoofstuk 33 het hy Job slinks en indirek tot 'n skuldbelydenis probeer beweeg. Hier word dit egter direk 
gedoen. Hy berei selfs die inhoud (v 31-32) daarvan vir Job voor. Maar weer die ironie: Job wat sonder skuld is, moet dit bely! Die retoriese vraag in vers 33 bevestig Elihu se siening van God: Hy vergeld of vergewe altyd met aanwysbare redes. In vers 33 kan Job slegs kies om skuld te bely, nie om onskuldig te pleit nie.

Die hoofstuk word deur 'n inclusio afgerond wanneer Elihu hom in vers 34-37 weer tot sy geesgenote die "wyses" wend. So "naby" is hy aan hulle dat hy sommer namens hulle 'n uitspraak formuleer: Job se onkunde en gevolglike skuld (v 35). In vers 4 het hulle (vgl die chiasme) besluit om te oordeel en die uiteindelike oordeel is "oorwoë" (v 35 ook 'n chiasme). Die by voorbaat skuldigbevinding in vers 1-9 word hier voltrek (vgl ook v 36-37). Die wens in vers 36 impliseer verdere skuldigbevinding. "Wat 'n hofsaak!" 55 sou die verstomde reaksie van die implisiete lesers kon wees.

\subsection{Al is God hoog en verhewe, is Hy regverdig}

In hoofstuk 35:1 stel die verteller weer vir Elihu aan die woord. Die hoofstuk word in drie dele onderverdeel: vers 1-4: Elihu reageer op Job se aantyging van God se onregverdigheid; vers 5-13: al is God transendent en swygsaam is Hy tog regverdig; vers 14-16: God se swye gee nie vir Job gelyk nie.

Elihu het tot dusver reeds probleme met Job se standpunt oor sy onskuld (vgl die vorige hoofstuk). As Job se sogenaamde "onskuld" en die bedenklike volhou daarvan (vgl ook 34:9) soos geïmpliseer deur die retoriese vraag (v 3), reflekteer op God se regverdigheid (v 2), dan moét Elihu "praat". Hy doen dit soos te wagte: "Ék sal antwoord...". Hy onderrig sommer die vriende óók al is Job die eintlike probleem.

In vers 5-13 begin Elihu God se transendensie (v 5 "hemel" sy domein) "op-die-man-af" verdedig deur die imperatiewe "kyk", "sien" en "aanskou". Hy "eggo" Job se retoriese vraag vier keer (ook deur מַ) in vers 6-7 (vgl ook die anafoor in beide verse) om God se onaantasbaarheid te benadruk. Sonde en geregtigheid raak net mense (vgl v 8 wat 6 en 7 in twee versbene opsom). Die implikasie is duidelik. God hoef hom nie aan mense te steur nie. Die intense geroep (chiasme) in vers 9 spruit uit mense se eiebelang (sonde) en daarom ignoreer God dit met beslistheid (vv 12-13, vgl die chiasme in v 13). Job word saam met hulle geïmpliseer. Opregte optrede teenoor God word in vers 10 en 11 beskryf. Anders as wat Job in 12:7-8 beweer dat ook die diere uitgelewer is aan God se willekeur is die natuur vir Elihu 'n leerskool en bron van wysheid (Spr 6:6-8). Die stam שור (vv 5,13) bind hierdie onderdeel netjies deur inclusio saam. 
Vers 14-16 begin deur anadiplose weer met dieselfde stam: Job sién God nie ${ }^{56}$. God wat Job se regsaak ignoreer, is analoog aan wat in die voorafgaande deel gebeur: Dit is ook 'n "geroep", maar uit "sonde" (Job is mos skuldig). Ewe eens hoéf en wil God Job nie antwoord nie. So bevind Elihu Job wéér skuldig en eindig hierdie hoofstuk (v 16) soos die vorige (vv 34:37).

\subsection{God se wonderlike en regverdige heerskapy in die skepping}

In hoofstuk 36-37 voer Elihu 'n lang aaneenlopende afsluitingsbetoog ter verdediging van God se regverdigheid. Die volgende onderdele kan onderskei word: vers 2-7: Elihu verdedig homself en vir God; vers 8-15: God "praat" en red deur lyding (algemeen); vers 16-21: God "praat" en red deur lyding; vers 22-25: God is verhewe en regverdig. Hiervandaan fokus Elihu op God se verhewenheid en indirekte spreke deur die skepping: deur reën, wolke en donderweer (v 26-31), deur weerlig (v 3237:4), deur winterkoue (v 5-10), weer deur wolk en weerlig (v 11-13). In vers 14-20 ontmasker Elihu Job se "onkunde" deur retoriese vrae oor die wonder van die skepping. Vers 21-24 vorm die hoogtepunt in Elihu se betoog met klem op God se oorweldigende grootheid en regverdigheid.

In hoofstuk 36:1 laat die verteller Elihu voortgaan met sy gesprek. Elihu se aanslag begin in vers $2-3$ meer hoflik: "Wag 'n bietjie..." 57 . Feitlik onmiddellik daarna kry sy ethos egter weer 'n gevoelige knou. Enersyds is hy bevooroordeeld en hy wil God se reg verdedig (vgl ook hoofstuk 35), want by Job is dit dan nie nodig nie (vgl ook vv 5-7). Andersyds is hy egter die opgeblasenheid vanself. Hy "word" weer God. Elihu wat homself in vers 4 beskryf as die "volmaakte in kennis" sinspeel op God wat só is (37:16). Vers 4 begin soortgelyk as 34:12 waar God beskryf word. Hy gaan haal sy kennis van vér af (v 3) soos God (2 Kon 19:25) en soos die grote Salomo (vgl 1 Kon 4:29-34) van ouds. God is rég, want hy tree volgens die vergeldingsdogma op. Hy straf die goddeloses en $\mathrm{Hy}$ is regverdig. Die chiasme in vers 6 bevestig dat Hy voorspelbaar is. Die implikasie van vers 7 is dat Job (op die ashoop) skuldig is, want regverdiges sit saam met konings.

In vers 8-15 bou Elihu op sy verdediging van die vergeldingsdogma voort. Hy sluit by 33:12-30 aan waar God deur lyding en swaarkry die sonde openbaar. "Kettings" en "bande van nood" (die $\square$ 'uitgange in v 8 se eerste versbeen is opvallend) wys heen na "dade" van sonde (v 9). Die chiasme beklemtoon dié dade en sinspeel soos in vers 6 op die "voorspelbaarheid" van die vergelding. Vers 11 is weer 'n bewys dat 
Elihu vir Job nie "wil hoor nie". Hy haal Job aan (7:1-2), maar gooi die eintlike punt wat Job wil maak by die venster uit ${ }^{58}$. Elihu sê "dien" het goeie gevolge (vergeldingsdogma). Job het dit egter tevergeefs gedoen (teen die vergeldingsdogma). Daad en gevolg in vers 11-12 word wéér effektief onderstreep deur die klankgelyke eerste versbene van vers 11 en 12 en die chiasme in vers 12 . Die halsstarriges van vers 13 se ondergang in 14 word ook "voorspelbaar" deur chiasme uitgebeeld" ${ }^{59}$ Vers 15 som 33:12-30 ("redding deur lyding") in 'n neutedop op 60 , met klankspel tussen לחיץ en weer 'n chiasme (ellendige, deur lyding, deur verdrukking,

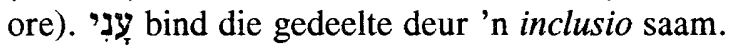

In vers 16-21 illustreer Elihu die voorafgaande argument deur dit direk op Job toe te pas. In vers 8-15 het hy oor "hulle" gepraat en Job indirek geïmpliseer. Hier praat hy egter direk met Job ("jy"). In vers 18, 20 en 21 waarsku Elihu Job "op-die-man-af”, maar darem (volgens Elihu) vir sy eie beswil ${ }^{61}$. Deur lyding wil God ook vir Job red: daarom verlos hy hom van שָָׁ en in plaas van die gulsige Mot beoog God vir hom 'n feesmaal62. In plaas van "vol" van heerlike voedsel, is Job "vol" (vgl die anadiplose) van sy sug na 'n regsaak (v 17). Job is weer skuldig: sy saak (T) het Elihu lankal besluit is dié van 'n goddelose ( Hebreeus is nie baie duidelik nie ${ }^{64}$, maar die punt waarom dit gaan is dat Job hom onmoontlik (vgl ook die retoriese vraag in $v 19$ ) uit sy skuldigbevinding kan loskoop. Die waarskuwings in vers 20-21 (vgl die chiasme in $\mathrm{v} 21$ ) wil Job weerhou daarvan om "op dun ys" te beweeg. Iemand wat skuldig is, moenie aanhou om sy nek styf te maak nie (v 20), maar moet sy skuld erken, anders kom totale vernietiging in die plek van ellende (v 21) 65 .

In vers 22-25 fokus Elihu pertinent op God: "Kyk, God..." (vgl ook 36:5,26). Deur die retoriese vrae (vv 22,23) wil Elihu instemming hê dat God groot en regverdig is. Sy regverdigheid (v 23) verwys terug na waar Elihu dit al so dikwels verdedig het. Sy grootsheid ( $v$ 22,23) antisipeer wat verder gaan volg. Job moet wegkom van twyfel aan God se "dade" van regverdigheid en eerder fokus (impt זכר) op God se "dade" in die skepping (vgl die anadiplose van פעל in vv 23-24). Dit moet hy doen saam met andere (beklemtoon deur die chiasme tussen v 24 en 25 se laaste versbene en v 24 se laaste en v 25 se eerste). God se skepping sal Job ook "antwoord".

Die "antwoord" begin in vers 26-31. Met "Kyk, God..." begin die onderdeel soos die vorige. Sy ontelbare jare dui op groot wysheid teenoor die vriende se baie jare, maar sonder wysheid $(32: 6 b-10)$. Sy grootheid kom na vore deur reën (-vorming) ${ }^{66}$, wolke en donderweer ${ }^{67}$ 
(onderstreep deur die retoriese vraag) en sy weerlig wat tot aan die eindes van die see versprei (onderstreep deur die chiasme).

Vers 32 tot 37:4 bou voort op die beskrywing van die storm,

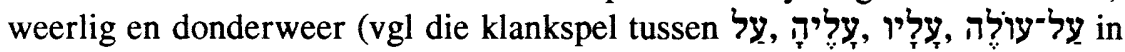
32-33). Vers 33 is onduidelik en sinspeel moontlik op die vernietiging68 van die goddelose. Paronomasia tussen (ֵָ (toorn) in vers 33 en (ja) in 37:1 lei op 'n subtiele wyse Elihu se "ontroering" in. Hy maak hier van die enkele kere van pathos gebruik. Sy eie emosionele "ontroering" (vrees) moet ook vir Job "beweeg" om na God te luister en voor Hom te buig. Dit volg hy met vers 2 op: "Luister, luister..." en verdere beskrywings van die weerlig ( $v$ 3: chiasties) en donderweer ( $v$ 4a-b: chiasties en klankspel

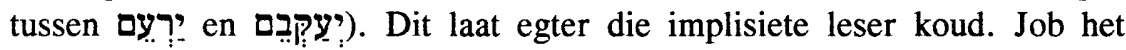
geen probleme met God se wonderlike almag in die skepping nie, wel met God se moraliteit ${ }^{69}$. Elihu mag dink dat God "antwoord", maar oor Job se onregverdige lyding swyg Hy tot dusver.

Vers 5-10 gaan met God se openbaring deur die weerverskynsels voort en verwys ook terug na vers 4a en 36:26. Hier gaan dit oor die winter, sneeu, stortreëns en koue. Die chiasmes in vers 7 (mense wat ophou werk), vers 8 (diere wat hiberneer) en tussen vers 8 en 9 se eerste versbene, "die diere ín die skuilplekke in" en "uit die skuilplek die stormwind", onderstreep die orde in die natuur (vgl ook die klankspel

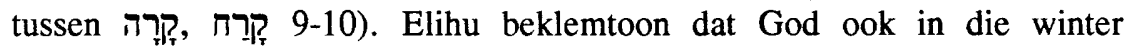
"praat". In vers 11-13 is Elihu weer terug by die wolke en weerlig soos in 36:26-31 en vat hy saam ${ }^{70}$ wat tot dusver gesê is. God is in beheer van wolk en weerlig oor die hele aarde, tot die aarde ( $\mathrm{vgl}$ die anadiplose met $\mathrm{v}$ 12) se nadeel of seën daarvan (vgl 36:31).

Elihu se "toon" verander in vers 14-20 deurdat hy Job weer aggressief en “op-die-man-af” konfronteer. In vers 14 word dit veral deur die talle retoriese vrae oor die skepping gedoen. Die retoriese vrae antisipeer God se vrae in hoofstuk 38. Hier "speel" Elihu soos voorheen weer God ${ }^{71}$. Elihu wil deur die retoriese vrae in vers 15 en 16 oor die beweging van wolke en weerlig Job se onkunde onderstreep. Job kan nie die Volmaakte in kennis (vgl ook $36: 45$ by implikasie dus ook Elihu) antwoord nie. Vers 16 vorm 'n chiasme en vers 15 en 16 'n inhoudelike chiasme wat die wonderlike orde van God se skepping subtiel onderstreep. Beide verse sinspeel op die warm somer wat aanbreek, wanneer die Sirocco waai en die wolke plat teen die hemelruim "gehamer" is" ${ }^{72}$ Die

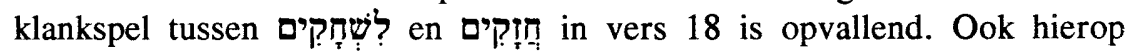
moet Job swyg. Hy weet nie hoé God dit doen nie. Die retoriese vrae bring weer die gevegsgrond in die prentjie, naamlik die vergeldingsdogma. Hoe 
kan iemand wat nie hierdie antwoorde ken nie, vir God verdag wil maak deur Hom as onregverdig te beskou ${ }^{73}$. Op die hoogtepunt van hierdie bombardement drup Elihu se woorde van sarkasme ${ }^{74}$ (v 19; let op die klankspel van die middelste elemente): "Leer jy óns wat óns Hom moet antwoord...". Nog nooit het Elihu hom sáám met Job geskaar nie, allermins as sy "advokaat". Die laaste retoriese vraag (ook chiasties) beklemtoon die onmoontlikheid van 'n regsgeding. Job is skuldig (soos vroeër reeds), "onkundig" en verward. Sy saak is "duisternis" (v 19).

Elihu beweeg na die hoogtepunt van sy betoog in vers 21-24 (eggo ook v 26-31). "Nou" vestig die aandag op die eintlike finale punt wat Elihu wéér wil inskerp ${ }^{75}$. God se verskyning uit die noorde is ontsagwekkend en oorweldigend soos wanneer die son deur die wolke breek (v 21-22). 'n Mens (Job word geïmpliseer) sal hierdeur vernietig word. God is verhewe, transendent en absoluut regverdig. Hy hoef nie te "antwoord" 76 nie (v 23; antwoord verwys terug na ענה as regsantwoord). Job wag tevergeefs op 'n direkte antwoord in 'n regsgeding. "Vrees God soos ander mense" (v 24), so sluit Elihu sy raad aan Job volgens die tradisionele wysheidsleer af ( $\mathrm{Spr}$ 1:7; Job 28:28). Selfs wyse mense "sien" Hom nie, Job nog minder. Die grand finale verdediging van die deus absconditus deur Elihu, word onmiddellik hierna deur die deus ex machina tot niet gemaak: 38:1: "En Jahwe het Job uit die storm geantwoord...". Hiermee word finaal met Elihu en voorlopig ook met die tradisionele vergeldingsdogma afgereken. In die epiloog kry dit die finale nekslag.

\section{SLOTSOM}

Elihu as karakter word konsekwent, meedoënloos (hoewel subtiel) en ironies ontmasker. Hoe hard Elihu ook al probeer om homself "hoorbaar" te maak, die "stem" van die implisiete outeur ontbloot en veroordeel hom. Dit lei die implisiete leser tot 'n volledige verwerping van Elihu en sy waardesisteem, naamlik die tradisionele vergeldingsdogma. Elihu se poëtiese welsprekendheid word kontra-produktief. Hoe méér hy praat, hoe minder sê hy. Die platform wat hom gegee word om sy saak te stel (solank as hy wil), word 'n valdeur. Sy "op-die-man-af" styl sou hom nog vergewe kon word, want hy praat darem in 'n "hof" tussen ander mans. Sy sogenaamde "reguit wees" blyk egter niks anders nie as jong, impulsiewe, kortsigtigheid te wees. Elihu wil so graag die reddende held wees. Die een met die "antwoord", die een geskik om Gód te verdedig (sy ethos en pathos), maar hy word ontbloot as 'n dwaas. Elihu word 'n ellelange monoloog gegun, net maar om stilswyend geïgnoreer te word. Ons hoor 
nie weer van hom nie. Die stilswye op sy stortvloed woorde is verdoemend ${ }^{77}$. Die implisiete leser snap die subtiele wenk dat die waarheid van Spreuke 26:4 hier toegepas word.

Habel beskryf die rol van die Elihuredes en die geheelopbou van Job as 'n doelbewuste, ironiese antiklimaks ${ }^{78}$. Die intrigelyn word heeltemal vertraag. God se antwoord uit die stormwind (38:1), wat net ná Job se sogenaamde uitdaagrede (29-31) verwag word, word vir lánk (6 hoofstukke) uitgestel. Good ${ }^{79}$ verwoord die gevoel van menige uitlegger van Job: "The delay is too long", sodat iets van die spanningseffek verlore gaan. In hierdie antiklimaks, hierdie byna oordrewe vertraging van die storielyn, lê egter 'n besondere funksionele effek opgesluit. Die antiklimaks word 'n verdere kragtige ontmaskeringstegniek. Weer moet gevra word na die "hoekom"? van die invoeging van die Elihuredes op hierdie punt in die Jobverhaal. Hierdie lang "stop" wil vir eens en vir altyd illustreer hoe die oplossing vir Job se probleem nié gesoek moet word nie. Die Elihuredes word as 't ware 'n negatiewe "tugroede" (vgl Paulus se siening van die wet) en as dit dan as 'n "straf" beleef word: wéér Good: "Dealing with good poetry is hard and exhilarating. Dealing with Elihu is just hard" 80 , dan is die gewenste effek hiermee bereik. Die implisiete leser het geen twyfel waar om nié langer te talm nie, om dan verder te beweeg na die ontknoping van die verhaal vanaf hoofstuk 38 en verder.

Die retoriese (kommunikatiewe) situasie van die Elihuredes is dié van 'n "hofgeding". Die retoriese situasie word gekonstitueer deur 'n skrywer se perspektief of sy oordeel van wat die probleem of behoefte van 'n bepaalde situasie sou wees, en wat dus ook kan verskil van die werklike historiese situasie. Hierdie "probleem" bepaal die wyse en inhoud van 'n diskoers ${ }^{81}$. Die "probleem" of behoefte vir die noodsaak van die invoeging van die Elihuredes in Job is die kritiese bevraagtekening van die tradisionele vergeldingsleer. Daar kon dalk geoordeel word dat die vergeldingsleer nog nie genoegsaam ontbloot is as dwaasheid ("folly") ${ }^{82}$ nie, en hiervoor sou die "hofgeding" van Elihu ideaal geskik wees. Hoewel Elihu se hofsaak om God regverdig en Job skuldig te bevind, word dit weer eens ironies, 'n hofsaak waarin Elihu en die vergeldingsdogma, "skuldig" bevind word. Elihu wat so graag "getuienis" aanhaal, se hele gesprek word verdoemende "getuienis" teen homself. Hierdeur kry die Elihuredes 'n soortgelyke funksie as Job 28, 'n subtiele vooruitgryp na die oplossing van die boek Job ${ }^{83}$. Elihu se "skuldigbevinding" antisipeer God se "uitspraak" in die epiloog. Die "transaksie" wat hier tussen skrywer en lesers aangegaan word, is dus 'n kritiese oordeel en afwysing van daadgevolg-denke. 
Implisiete outeur en implisiete lesers gee nie 'n een-tot-een toegang tot die werklike skrywer en lesers nie, maar gee ten minste suggesties in welke kringe hulle (histories) gesoek behoort te word. Habel meen dat die "skrywer" van Job 'n kritiese wysgeer Israeliet is ${ }^{84}$. "Skrywer" moet eerder kollektief verstaan word, naamlik skeppende skrywers en latere redakteurs wat eensgesind was in hulle protes teen die vergeldingsleer. Die Elihuredes is waarskynlik sekondêr in die boek Job ingevoeg, maar beslis nie "lomp" en onpas nie. Daarvoor is hierdie redes té ingeweef in die res van die boek, literêr en pragmaties vir die funksie wat dit moet verrig. Die implisiete lesers wys in die rigting van 'n kritiese gehoor, wat geskool was in die wysheidsperspektief en wat die waardesisteem van die skrywers, naamlik proteswysheid, gedeel het. Die Elihuredes wil dus juis nie 'n lansie breek vir die ortodokse standpunt nie. Ironies genoeg bevestig die Elihuredes juis Dell ${ }^{85}$ se standpunt. Sy beskou die Elihuredes as lomp en onpas omdat dit nie 'n parodiëring van tradisionele vorme bevat nie en die ortodokse standpunt ter wille is. Die boek Job se gehoor sien sy as 'n skeptiese groep wat op die rand van die wysheid staan, soortgelyk aan en kort voordat die Griekse "skeptici” op die toneel begin verskyn het. Die implisiete lesers van die Elihuredes "wys" inderdaad in hierdie rigting.

Die teks self, maar ook dit wat "tussen die lyne" en "agter die teks" staan bevestig die grootsheid van die Jobverhaal. Ook die Elihuredes is 'n demonstrasie van subtiliteit, onderbeklemtoning en uiters effektiewe kommunikasie: ingewikkelde lewensvrae kan nie met simplistiese antwoorde soos dié van Elihu opgelos word nie.

\section{NOTAS:}

J A Loader, "Die boek Job", in: Tweegesprek met God: predikers, digters en wysgere, (LOT 3), J J Burden en W S Prinsloo (reds), Kaapstad 1987, 2; H M Wahl, "Ein Beitrag zum alttestamentlichen Vergeltungsglauben am Beispiel von Hiob 32-37", BZ 36 (1992), 254-255.

Vergelyk onder andere K J Dell, The book of Job as sceptical literature, (BZAW 197), Berlin 1991, 198; Wahl, $a w, 255$; A Lacocque, "Job or the impotence of religion and philosophy", in: The book of Job and Ricoeur's hermeneutics, (Semeia 19), J D Crossan (ed), Chico 1981, 40.

Vergelyk onder andere N C Habel, The book of Job, (OTL), London 1985 en "The role of Elihu in the design of the book of Job" in: In the shelter of Elyon (Essays on Ancient Palestinian life and literature in honor of $G W$ Ahlström, W B Barrick and J R Spencer (eds), (JSOT suppl 31), Sheffield 
1984, 81-98; E Good, In turns of tempest: $A$ reading of Job with a translation, Stanford 1990, 319-337.

J A Loader, "Die rebel wat die waarheid oor God gepraat het" in: Menswaardig: God, mens en wêreld, C J A Vos en J C Müller (reds), Halfweghuis 1994, 88, beklemtoon dat die verwaarlosing van die geheelkonteks van Job fataal is.

Vergelyk hier veral E C Traugott \& M L Pratt, Linguistics: For students of literature, New York 1980, 226, 229; J N Vorster, The rhetorical situation of the letter to the Romans - An interactional approach (DD thesis) University of Pretoria, 1991, 21; T J Keegan, Interpreting the Bible: A popular introduction to biblical hermeneutics, New York 1985, 79; D Patrick \& A Scult, Rhetoric and biblical interpretation, (JSOT Suppl 82), Sheffield 1990, 18,19,96,97; E N Goody, “Introduction" in: Questions and politeness: Strategies in social interaction, E N Goody (ed), London 1978, 10.

D Patrick \& A Scult, $a w, 15 ;$ Traugott \& Pratt, $a w, 255$.

Goody, $a w, 2$.

$8 \quad$ Traugott \& Pratt, $a w, 241$.

$9 \quad \mathrm{~J}$ N Vorster, $a w, 256$.

Ibid.

Y Gitay, Prophecy and persuasion: A study of Isaiah 40-48, Bonn 1981, 35.

Hier word gesteun op die insigte oor implisiete outeur en implisiete leser van onder andere B C Lategan, "Coming to grips with the reader in biblical literature" en "Levels of reader instructions in the text of Galatians" en ook W S Vorster, "The reader in the text: Narrative material" in: Reader perspectives on the New Testament, (Semeia 48), E V McKnight (ed), Atlanta 1989, 3-17, 171-184, 21-39; J N Vorster, $a$ w; R M Fowler, "Who is 'the reader' in Reader Response Criticism" in: Reader response approaches to biblical and secular texts, (Semeia 31), R Detweiler (ed), Decatur 1985, 5-23; Keegan, $a w$.

13 P Brown \& S Levinson, "Universals in language usage: Politeness phenomena" in: Questions and politeness: Strategies in social interaction, E N Goody (ed), London 1978, 56-310.

J N Vorster, $a w, 65$

Vergelyk Habel, $a w, 1984$, en $a w, 1985$. 
Vergelyk ook אִגְנְשים in vers 1 en 5.

Habel, $a w, 1985,448$.

Ibid, 445. Hy toon ook aan dat tien van die sestig voorkomste van ענה Job in hoofstuk 32 voorkom.

Vergelyk J C Anderson, “Double and triple stories, the implied reader, and redundancy in Matthew" in: Reader response approaches to biblical and secular texts, (Semeia 31), R Detweiler (ed), Decatur 1985, 72, waar die implisiete outeur en betroubare verteller in Matteus saamval en J N Vorster, $a w, 62$ waar dit in Romeine 2 gebeur. Vergelyk ook Habel, $a w, 1984,81$ vir die saamval van "stemme" in die teks.

W S Vorster, $a w, 23$.

Vergelyk Brown \& Levinson, $a w, 112$ wat hierna verwys as die sogenaamde "vivid present".

F E Deist, "Verteltekste" in: Woorde wat ver kom, (LOT 1), F E Deist, W S Vorster (reds), Kaapstad 1986, 95.

Habel, $a w, 1984,94$.

Vir die segmentering van onderdele deurgaans word daar sterk gesteun op L C Bezuidenhout, Struktuur en strekking van die boek Job (DD proefskrif), Universiteit van Pretoria, 1986 en ook Habel, $a w, 1985$.

“Point-of-view” switch, vergelyk Brown \& Levinson, $a w, 123$.

Brown \& Levinson, $a w, 136$.

Ibid.

Habel, $a w, 1985,449$.

$31 \quad$ Brown \& Levinson, $a w, 101$.

Habel, $a w, 1985,452$.

Ibid, 453. 
Habel, $a w, 1985,443-444$.

Vergelyk Gitay, $a w, 37$, vir die uiteensetting van hierdie retoriese tegniek.

Habel, $a w, 1985,444$.

A van Selms, Job: Een praktische bijbelverklaring, (T\&T), Kampen 1984, 164.

Habel, $a w, 1985,449$.

M H Pope, Job: Introduction, translation and notes, (AB), New York ${ }^{3} 1974$, 247; Vergelyk ook Brown \& Levinson, $a w, 247$.

Grice se "maxim of sincerity" is hier ter sprake, vergelyk Brown \& Levinson, $a w, 100$.

Pope, $a w, 248$.

\section{Ibid.}

Habel, $a w, 1985,467$.

Ibid, 468.

Van Selms, $a w, 164$.

Habel, $a w, 1985,462$, sien ook hierin 'n ooreenkoms met die klaagpsalms wat ontwikkel van lydensklag tot lof.

Ibid, 463,470 .

Habel, $a w, 1984,90$.

Brown \& Levinson, $a w, 106 \mathrm{ev.}$

Ibid, 75.

Goody, $a w, 30$.

Vergelyk Bezuidenhout, $a w, 356$, en die tekskritiese emendering, nota 18a.

Ibid. Vergelyk ook tekskritiese nota $20^{\mathrm{b}-\mathrm{b}}$.

Gepas word dit as 'n "kangaroo court” beskryf, Habel, a w, 1985, 478. 
Habel, $a w, 1985,490$.

57 Hier word van 'n sogenaamde "hedge" gebruik gemaak om die bevel te versag ("bietjie"), vergelyk Brown \& Levinson, $a w, 150 \mathrm{ev}$.

$58 \quad$ Habel, $a w, 1985,507$.

59 Bezuidenhout, $a w, 377-378$, se vokalisering van ptom "heilige gawes" te beteken in plaas van "tempelprostitute", verbreek egter die chiasme van die betrokke versbeen.

$60 \quad$ Pope, $a w, 270$.

$61 \quad$ Brown \& Levinson, $a w, 103$.

62 Habel, $a w, 1985,509$ beskou die feesmaal (myns insiens korrek) as iets wat in die toekoms lê en nie in die verlede (bv Nuwe Afrikaanse Bybelvertaling) nie.

Ibid.

$64 I b i d$, vergelyk 495 vir 'n vertaling. Vergelyk ook Bezuidenhout, $a w, 374$, 379 vir emenderings aan die teks en die gevolglike vertaling.

Vergelyk weer Bezuidenhout, $a w, 374,379$ vir die vertaling van die onduidelike Hebreeus.

Die tekskritiese voorstelle in vers 27 word aanvaar.

67 Hier mag moontlik van onomatopee sprake wees deur die u-o-assonansie.

$68 \quad$ Vergelyk Bezuidenhout, $a w, 375,380$.

$69 \quad$ Habel, $a w, 1985,506$.

$70 \quad$ Bezuidenhout, $a w, 397$.

$71 \quad$ Pope, $a w, 284$.

72 Bezuidenhout, $a w, 376,381$.

$73 \quad$ Pope, $a w, 284$.

$74 \quad$ Bezuidenhout, $a w, 398$; Habel, $a w, 1985,515$.

75 Vergelyk Brown \& Levinson, $a w, 174$. "Nou" is 'n aanduiding dat die sogenaamde "maxim of relevance" ingespan word. 
76 ענה word met goeie gronde deur Habel, $a w, 1985,501$ gevokaliseer om "antwoord" te beteken. Vergelyk ook Bezuidenhout, $a w, 377$.

77 Vergelyk ook W S Vorster, $a w, 26$ wat wys op die “wenk" aan die implisiete leser deur stilswye van die Markusslot.

$78 \quad$ Habel, $a w, 1984,92$.

$79 \quad$ Good, $a w, 337$.

$80 \quad$ Ibid.

$81 \quad$ J N Vorster, $a w, 53 \mathrm{ev}$

$82 \quad$ Habel, $a w, 1984,96$.

$83 \quad$ Loader, $a w, 1987,2$.

$84 \quad$ Habel, $a w, 1985,40$.

$85 \quad$ Dell, $a w, 198$ 